J. Clin. Chem. Clin. Biochem.

Vol. 23, 1985, pp. $41-44$

\title{
Stabilization of the Substrate Reaction of Horseradish Peroxidase with $o$-Phenylenediamine in the Enzyme Immunoassay
}

\author{
By T. Porstmann \\ Institute of Medical Immunology
}

Bärbel Porstmann

Institure of Pathological and Clinical Biochemistry

R. Wietschke and $R$. von Baehr

Institute of Medical Immunology

E. Egger

Institute of Pathology and Clinical Biochemistry,

Faculty of Medicine (Charité), Humboldt-University of Berlin (GDR)

(Received June 21/October 8, 1984)

Summary: When the horseradish peroxidase reaction is stopped with acid, the decay of unconverted hydrogen peroxide is responsible for the further oxidation of $o$-phenylenediamine. This leads to a time-dependent flattening of the standard curve in the enzyme immunoassay, after the reaction has been stopped. Addition of reducing agents, such as sulphite ions, to the stopping solution, prevents the further oxidation of $o$-phenylenediamine by completely reducing the remaining hydrogen peroxide. The developed colour is then stabilized.

Stabilisierung der Substratreaktion mit o-Phenylendiamin und Wasserstoffperoxid für Meerrettich-Peroxidase im Enzymimmunoassay

Zusammenfassung: Nach Abbruch der Peroxidasereaktion durch Säurezugabe führt der Zerfall von nicht umgesetztem Wasserstoffperoxid zur weiteren Oxidation von o-Phenylendiamin, was zu einer Abflachung der Standardkurven im Enzymimmunoassay mit zunehmender Zeit nach Reaktionsabbruch führt. Der Zusatz von Reduktionsmitteln wie beispielsweise Sulfitionen zur Stopplösung verhindert durch Reduktion des verbliebenen Wasserstoffperoxids die weitere Oxidation von $o$-Phenylendiamin und stabilisiert die entwickelte Farbe.

\section{Introduction}

$o$-Phenylenediamine is one of the most frequently used chromogens for the determination of horseradish peroxidase. Under optimal reaction conditions a detection limit of about $2 \mathrm{ng} / \mathrm{l}$ horseradish peroxidase is observed (1), which enables highly sensitive enzyme immunoassays (EIA). A disadvantage of o-phenylenediamine, however, is its instability. It is therefore advisable to perform the reaction in the dark and to measure the colour intensity of the developed 2.2 diamino azobenzene immediately after stopping the reaction by addition of acid (2). 
Here we describe the stabilization of the developed colour by adding sulphite ions to the stopping solution. Sulphite reduces the remaining unconverted hydrogen peroxide after termination the enzyme reaction.

\section{Material and Methods}

All chemicals used in the experiments were of analytical grade.

Stability of substrate solution in absence of horseradish peroxidase

o-Phenylenediamine (VEB Laborchemie Apolda, GDR) was dissolved in $0.1 \mathrm{~mol} / 1$ citrate buffer, $\mathrm{pH} 5.0$ at a concentration of $20 \mathrm{mmol} / \mathrm{l}$; the concentration of $\mathrm{H}_{2} \mathrm{O}_{2}$ was $8.5 \mathrm{mmol} / \mathrm{l}$. One $\mathrm{ml}$ of the substrate solution was mixed with either $1 \mathrm{ml}$ of $2 \mathrm{~mol} / \mathrm{l}$ sulphuric acid or $4 \mathrm{~mol} / 1$ hydrochloric acid Suprapur ${ }^{\circledR}$ (Merck Darmstadt, FRG) with or without $0.1 \mathrm{~mol} / \mathrm{l}$ sodium sulphite. As a control the substrate solution was diluted 1:2 with citrate buffer. The different solutions were either exposed to diffuse light or stored in the dark. Absorbance was measured against distilled water at $20 \mathrm{~min}$ intervals over a period of $3 \mathrm{~h}$ and afterwards for another $15 \mathrm{~h}$ period every $3 \mathrm{~h}$. Nonenzymatic conversion of $\mathrm{H}_{2} \mathrm{O}_{2}$ catalyzed by-traces of metal ions was checked by addition of 'ethylenediaminetetraacetic acid (EDTA) to the citrate buffer as well as to the stopping solutions up to a final concentration of $1.0 \mathrm{mmol} / \mathrm{l}$.

Stability of oxidized substrate solution in the presence horseradish peroxidase

The influence of sodium sulphite on the stability of the developed chromophore was checked in an EIA for human $\alpha$ fetoprotein (AFP), the principle of which was described in detail recently $(3,4)$. Briefly: Solid phase supported anti-AFP reacts with standard or sample AFP, to which anti-AFP horseradish peroxidase-conjugate is bound in the next step. All reactants were incubated for $90 \mathrm{~min}$ at room temperature. Unbound reactants were removed after each incubation step by washing the tubes. Solid phase bound enzyme activity is directly related to the quantity of AFP. The substrate reaction, with $0.5 \mathrm{ml}$ solution of 0 -phenylenediamine and $\mathrm{H}_{2} \mathrm{O}_{2}$ in the concentrations described above, was performed in the presence or absence of light, and stopped after $25 \mathrm{~min}$ by addition of $0.5 \mathrm{ml} 2 \mathrm{~mol} / \mathrm{l}$ sulphuric acid or $4 \mathrm{~mol} / 1$ hydrochloric acid, with or without $0.1 \mathrm{~mol} / \mathrm{l}$ sodium sulphite. One part of each sample was further exposed to light the other was kept in the dark. Standard curves were recorded over a period of $3 \mathrm{~h}$ every $20 \mathrm{~min}$ followed by intervals of $3 \mathrm{~h}$ for a further $15 \mathrm{~h}$ using either distilled water or unconverted substrate solution diluted $1: 2$ with solutions of acids as blank values.

All determinations were carried out in triplicate and were measured on a Calculating Absorptiometer 2074 (LKB Producter, Stockholm, Sweden) at $495 \mathrm{~nm}$ after stopping with acid, and at $440 \mathrm{~nm}$ for the unstopped solution.

\section{Results}

Stability of the substrate solution in the absence of horseradish peroxidase

Colour development of the different substrate solutions during the investigated period is shown in

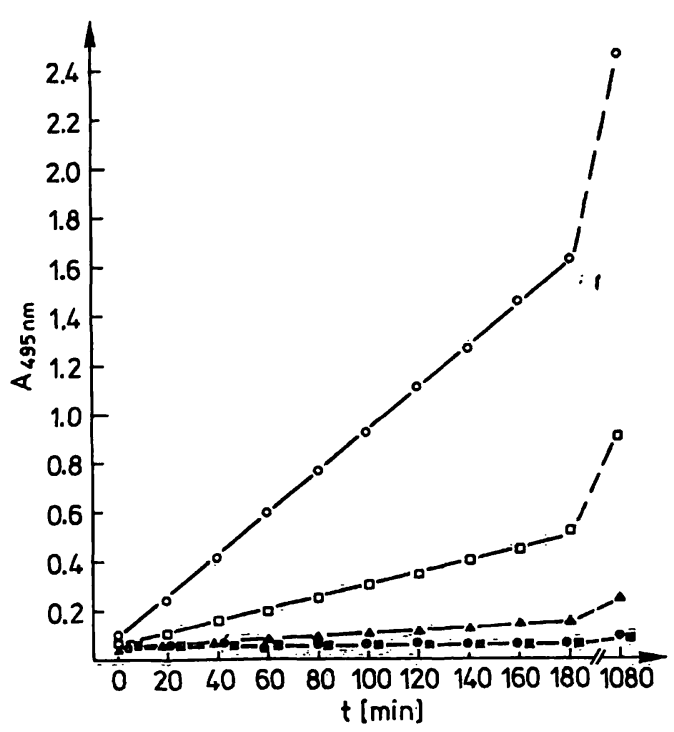

Fig. 1. Time course of absorbance of substrate solutions in the absence of horseradish peroxidase mixed with equal volumes of:

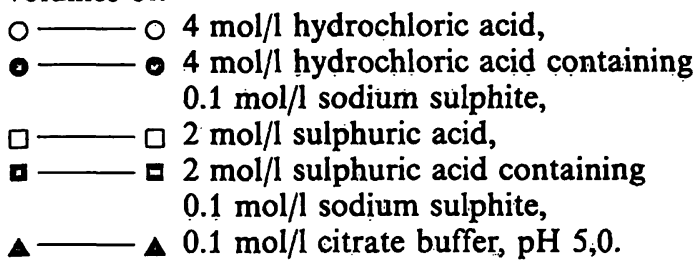

figure 1. Substrate solutions at $\mathrm{pH} 5$ are much more stable than at $\mathrm{pH}$ values around 1 . The addition of hydrochloric and sulphuric acid caused a 6.5 fold or a 3.5 fold increase of absorbance after $60 \mathrm{~min}$, irrespective of whether the samples were stored in the dark or not. EDTA did not prevent the absorbance shift, ruling out catalytic activity of metal ions in the system (data not presented here). All samples containing sulphite ions, however, resulted in constant absorbance values.

\section{Stability of the substrate solution in the presence of horseradish peroxidase}

The increase of absorbance after stopping the reaction with sulphuric acid was linear over the investigated time course $(\Delta \mathrm{A} 0.05 / \mathrm{h})$ and independent of the basic absorbance obtained by the enzymatic conversion of substrate. When hydrochloric acid was used to stop the reaction, the non-enzymatic substrate conversion at first showed zero order kinetics $(\triangle \mathrm{A} 0.51 / \mathrm{h})$, then became a first order reaction, due to a lack of available $\mathrm{H}_{2} \mathrm{O}_{2}$. However, in both cases no influence of light was observed on the increase of absorbance. Absorbances were completely stabilized during the first $3 \mathrm{~h}$ when sodium sulphite was added to the stopping solutions (fig. $2 a-c$ ). 

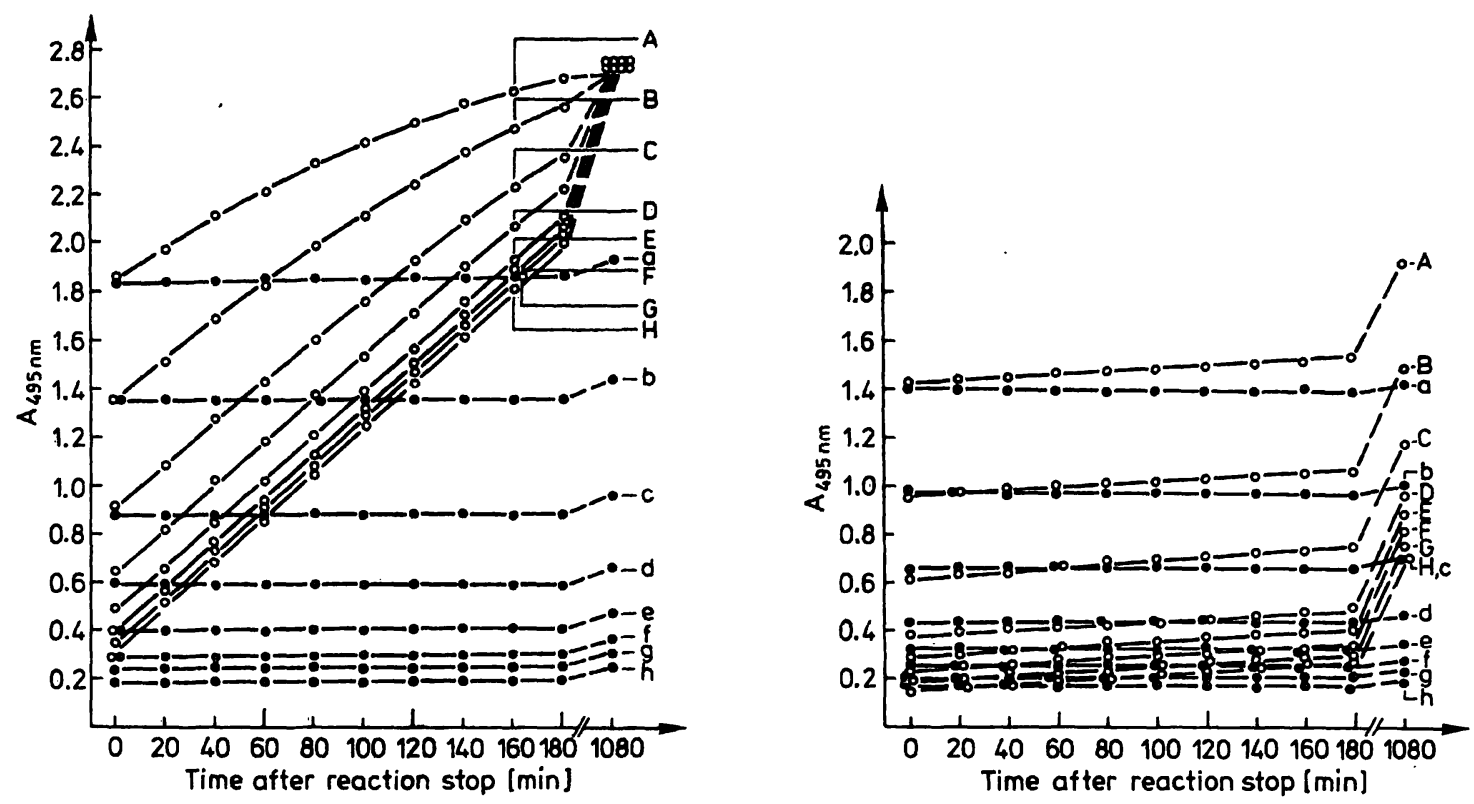

Fig. 2. Time course of absorbance produced by the different concentrations of $\alpha$-fetoprotein in the EIA after stopping the reaction: with:

$0-04 \mathrm{~mol} / \mathrm{l}$ hydrochloric acid,

- $4 \mathrm{~mol} / \mathrm{l}$ hydrochloric acid containing $0.1 \mathrm{~mol} / \mathrm{l}$ sodium sulphite (left side) and:

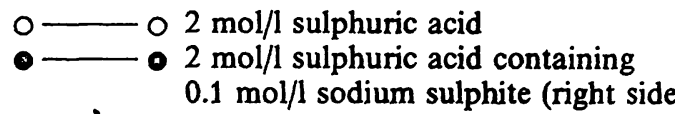

$\alpha$-Fetoprotein concentrations:

A, a $(26 \mu \mathrm{g} / \mathrm{l}), \mathrm{B}, \mathrm{b}(13 \mu \mathrm{g} / \mathrm{l}), \mathrm{C}, \mathrm{c}(6.5 \mu \mathrm{g} / \mathrm{l}), \mathrm{D}, \mathrm{d}(3.25 \mu \mathrm{g} / \mathrm{l}), \mathrm{E}, \mathrm{e}(1.6 \mu \mathrm{g} / \mathrm{l}), \mathrm{F}, \mathrm{f}(0.8 \mu \mathrm{g} / \mathrm{l})$.
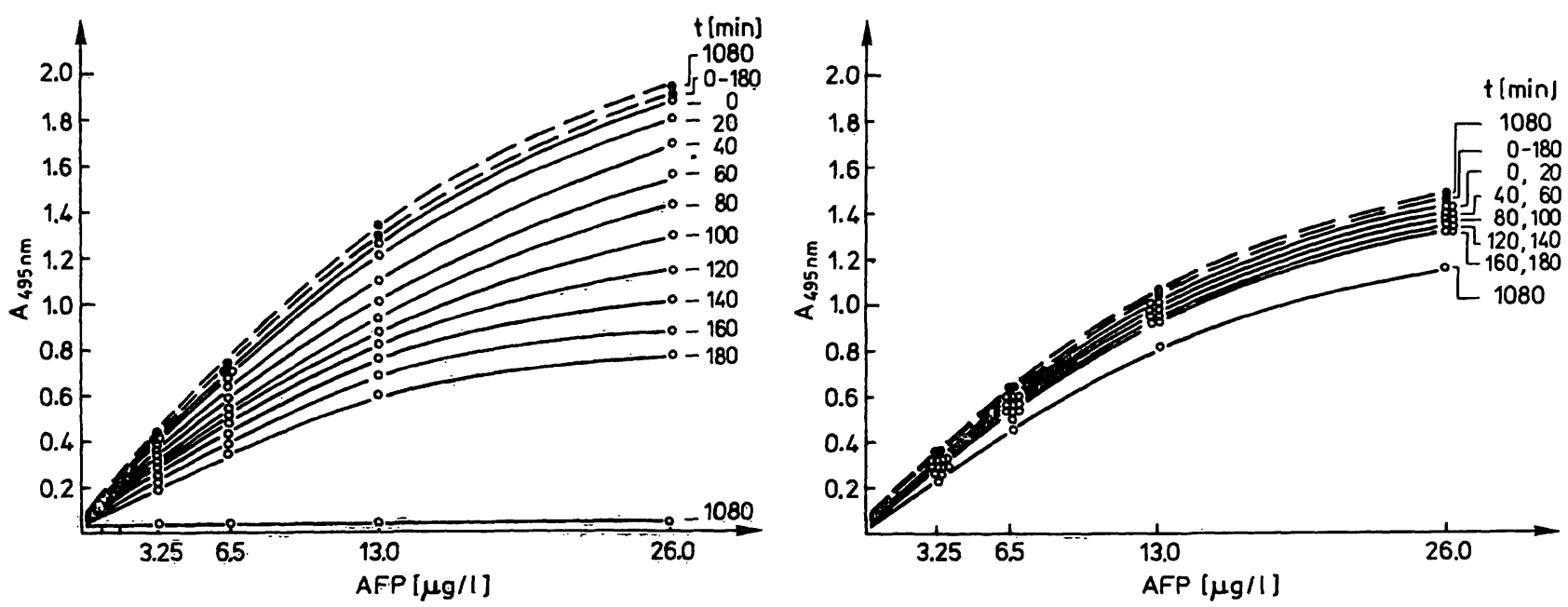

Fig. 3. Standard curves of the $\alpha$-fetoprotein EIA recorded at different times after stopping the reaction with: $0-04 \mathrm{~mol} / 1$ hydrochloric acid,

- - $4 \mathrm{~mol} / \mathrm{l}$ hydrochloric acid containing $0.1 \mathrm{~mol} / 1$ sodium sulphite (left side) and: $0-02 \mathrm{~mol} / \mathrm{l}$ sulphuric acid,

0 - $02 \mathrm{~mol} / \mathrm{l}$ sulphuric acid containing $0.1 \mathrm{~mol} / 1$ sodium sulphite (right side).

In the EIA, flattening of the standard curves was much more pronounced when substrate conversion was terminated by adding hydrochloric acid instead of sulphuric acid. Eighteen hours after stopping the reaction with hydrochloric acid, any differentiation between the AFP standard concentrations was impossible. Under similar conditions, but in the presence of sodium sulphite, however, the standard curve resembled those measured immediately after stopping the reaction (fig. $3 \mathrm{a}, \mathrm{b}$ ). 


\section{Discussion}

The instability of $o$-phenylenediamine solutions is caused by spontaneous decay of $\mathrm{H}_{2} \mathrm{O}_{2}$, and is much less affected by exposure to light than by the $\mathrm{pH}$ value of the solution. The decrease of the $\mathrm{pH}$-value as a result of the termination of the enzyme reaction is therefore the main reason for a further non-enzymatic conversion of $o$-phenylenediamine to 2.2-diamino azobenzene. But due to the inverse correlation of the absorbance coefficient of the 2.2-diamino azobenzene and $\mathrm{pH}(1)$, the use of acid to the reaction also intensifies the colour.

Although non-enzymatic 2.2-diamino azobenzene formation follows zero-order kinetics if sufficient quantities of unconverted $\mathrm{H}_{2} \mathrm{O}_{2}$ are available, the percent increase of absorbance depends on the basic absorbance produced by the enzymatic substrate conversion. Therefore low absorbance values representing small quantities of antigen resulted in a higher non-enzymatic increase than high absorbance values. This has already been demonstrated in an EIA for hepatitis B surface antigen (2), in which the standard curves flattened with time after the reaction had been stopped. This loss of analytical sensitivity cannot be tolerated especially when large numbers of samples are screened by eye to differentiate weakly positive from negative samples.

The undesired non-enzymatic substrate conversion after stopping the reaction may be prevented by reducing agents such as sulphite ions; / which hinder further 2.2-diamino azobenzene formation by the immediately and completely reduction of remaining $\mathrm{H}_{2} \mathrm{O}_{2}$.

The different effects of sulphuric acid and hydrochloric acid on the stability of the developed colour may be due to the presence of chlorine, which is a strong oxidant, in the hydrochloric acid. The addition of sulphite ions stabilized the reaction product of the horseradish peroxidase for many hours, irrespective of the kind of acid being used for stopping the reaction. It was not necessary to protect the samples from light, and furthermore it was possible to use much higher substrate concentrations (5). If hydroxyphenyl acetic acid is used as a fluorogenic substrate for the horseradish peroxidase, the strong increase of fluorescence after stopping the reaction with sodium carbonate can also be prevented by addition of sulphite (6).

\section{References}

1. Gallati, H. \& Brodbeck, H. (1982) J. Clin. Chem. Clin Biochem. 20, 221-225.

2. Porstmann, B., Porstmann, T. \& Nugel, E. (1981) J. Clin. Chem. Clin. Biochem. 19, 435-439.

3. Porstmann, T., Porstmann, B., Nugel, E., Micheel, B., Karsten, U. \& Fiebach, H. (1983) Clin. Chim. Acta 135, 13-22.

4. Porstmann, B., Porstmann, T., Schmechta, H., Nugel, E. Huse, K., Kopperschläger, G. \& Seifert, R. (1984) Z. Med. Labor.-Diagn. 25, 5-14.

5. Bovaird, J.H., Ngo, T. T. \& Lenhoff, H. M. (1982) Clin. Chem. 28, 2423-2426.

6. Nugel, E. Porstmann, B., Porstmann, T. \& Schmechta, H. (1984) Z. Med. Labor.Diagn.: in press.

Dr. T. Porstmann

Institute of Medical Immunology

Faculty of Medicine (Charité)

Schumannstraße 20/21

DDR-1040 Berlin 